
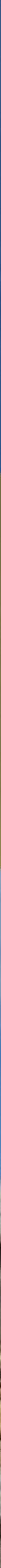


\section{Panta Rei \\ Revista Digital de Ciencia \\ y Didáctica de la Historia}

\section{6}

Revista anual

Fecha de inicio: 1995

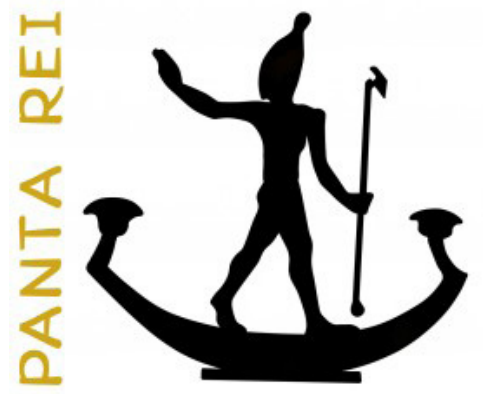

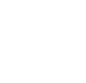




\section{CONSEJO DE REDACCIÓN}

\section{Coordinador editorial}

Egea Vivancos, Alejandro

[Didáctica de las Ciencias Sociales, UMU]

\section{Editores}

Botí Hernández, Juan Jesús

[CEPOAT, UMU]

Meseguer Gil, Antonio José

[CEPOAT, UNED]

Sáez Giménez, David Omar

[CEPOAT, UMU]

Sánchez Mondéjar, Celso Miguel

[CEPOAT, UMU]

\section{Secretaria}

Arias Ferrer, Laura

[Didáctica de las Ciencias Sociales, UMU]

\section{Responsable informático}

Martínez García, José Javier

[CEPOAT, UMU]

\section{Traducción y corrección lingüística}

Martínez Martínez, Cristina

[Sociedad Española de Lenguas Modernas]

Albaladejo Albaladejo, Sara

[ISEN, UMU]

\section{CONSEJO ASESOR}

Albero Muñoz, M. ${ }^{a}$ del Mar

[H. ${ }^{a}$ del Arte, UMU]

Chapman, Arthur

[History Education, UCL, Reino Unido]

Cobacho López, Ángel

[Derecho, UMU]

Egea Bruno, Pedro M. ${ }^{\text {a }}$

[Historia Contemporánea, UMU]

García Atienzar, Gabriel

[Prehistoria, UA]

González Monfort, Neus

[Didáctica de las Ciencias Sociales, UAB]

Haber Uriarte, María

[Prehistoria, UMU]

Hutson, Scott R.

[Anthropology, UK, EEUU]

Irigoyen López, Antonio

[Historia Moderna, UMU]

Mahony, Simon

[Digital Humanities, UCL, Reino Unido]

Marsilla de Pascual, Francisco Reyes

[Técnicas historiográficas, UMU]

Miralles Maldonado, José Carlos

[Filología Clásica, UMU]

Molina Gómez, José Antonio

[Historia Antigua, UMU]

Noguera Celdrán, José Miguel

[Arqueología, UMU]

Pérez Molina, Miguel Emilio

[Filología Clásica, UMU]

Prados Martínez, Fernando

[Arqueología, UA]

Sánchez Ibáñez, Raquel

[Didáctica de las Ciencias Sociales, UMU]

Sancho Gómez, Miguel Pablo

[Educación, UCAM]

Vilar García, María José

[Historia Contemporánea, UMU]

Zamora López, José Ángel

[Próximo Oriente Antiguo, CCHS-CSIC] 

Artículos

Los orígenes de la tecnología a debate: una revisión de las primeras industrias líticas.

Arturo Cueva Temprana.

De arqueología menorquina: Maria Lluïsa Serra Belabre y los círculos talayóticos de Sant Vicenç d' Alcaidús (Alaior, Menorca).

Octavio Torres Gomariz.

Nuevas cuestiones sobre el anfiteatro de Zaragoza.

José David Mendoza Álvarez.

Castidad o castigo. El estupro de las Vestales como símbolo de desorden social en Roma.

Juan Antonio Montalbán Carmona.

La Historia antigua en la Biblioteca de Focio.

Juan Luis Posadas Sánchez.

Usos sociales de la historia. La estrategia de Olga Cossettini, Rosario, 1935-1943.

Paula Caldo, Micaela Pellegrini Malpiedi y Agustina Mosso

Contribuciones a la didáctica de la Historia a través del método de análisis del objeto: como ejemplo... una "vasulla".

Nayra Llonch Molina y Verónica Parisi Moreno.

How are digital methods changing research in the study of the classical world? An EpiDoc case study. Katherine Steiner y Simon Mahony.

\section{Reseñas}

I Congreso Internacional "Creando ciudadanos, construyendo identidades. El uso del patrimonio material e inmaterial en la enseñanza de la historia."

José Díaz Serrano, Ainoa Escribano Miralles, Ana Isabel Ponce Gea y David Verdú González 151

Beckert, S. (2014). Empire of cotton: A global history. New York: Alfred A Knopf. 640 págs.

Ricky D. Mullins Jr..

Coumert, M. y Dumézil, B. (2013): Los reinos bárbaros en Occidente (traducción de Peinado Santaella, R. G.: Les royaumes barbares en Occident, Presses Universitaires de France, 2010). Editorial Universidad de Granada. Granada. 156 págs.

José Ángel Castillo Lozano.

La prehistoria en Las tres edades de Buster Keaton.

Alberto Lombo Montañés y Esther Rodríguez Ortiz.

Normas de publicación/Publishing rules 



\title{
How are digital methods changing research in the study of the classical world? An EpiDoc case study ${ }^{1}$
}

\author{
¿Cómo los métodos digitales están cambiando la investigación del \\ mundo clásico? El caso del EpiDoc
}

\author{
Katherine Steiner ${ }^{2}$ \\ Bodleian Libraries, University of Oxford \\ Simon Mahony ${ }^{3}$ \\ University College London
}

Recibido: $14 / 05 / 2016$

Aceptado: $24 / 07 / 2016$

Para citar este artículo: Steiner, K. y Mahony, S. (2016). How are digital methods changing research in the study of the classical world? Ap EpiDoc case study. Panta Rei. Revista Digital de Ciencia y Didáctica de la Historia, 125-148.

ISSNe: 2386-8864

DOI: $10.6018 /$ pantarei/2016/8

\section{Resumen}

Los Estudios Clásicos como disciplina siempre se han beneficiado del uso de la tecnología digital en la investigación, con proyectos que datan desde los años 70 e incluso de fechas anteriores. Este artículo examina la integración de los Estudios Clásicos y las nuevas tecnologías de la información y presenta un caso práctico en torno a EpiDoc, una lengua de marcado uso en epigrafía. Hay constancia de la influencia positiva de la introducción de EpiDoc: no solo cuenta con varios proyectos colaborativos en la actualidad sino que la naturaleza de su tecnología fomenta la investigación en abierto. Las inscripciones del proyecto de Aphrodisias son una muestra significativa del potencial de las publicaciones electrónicas basadas en este lenguaje. Aunque el efecto de EpiDoc en la propia investigación permanece todavía inconcluso, al contar con escasos ejemplos claros, hay una clara evidencia de las posibilidades de futuro que posee. La difusión de estas conclusiones a la amplia comunidad de humanidades digitales clásicas muestra una tendencia hacia la colaboración en publicaciones y proyectos recientes, así como una aceptación gradual de publicaciones electrónicas.

\section{Palabras clave}

Bibliotecas digitales, Proyecto colaborativo, Publicación electrónica, Fuentes Clásicas, Humanidades.

1 This article was originally written as part of a dissertation submitted in partial fulfilment of the requirements for the Master's degree in Information Science, University College London (UCL) in the academic session 2015.

2 Para contactar con esta autora: Katherine Steiner. Bodleian Libraries, Oxford. katherine.steiner1@gmail. com.

3 Para contactar con este autor: Simon Mahony. University College London. s.mahony@ucl.ac.uk. 


\begin{abstract}
Classics as a discipline has always taken advantage of digital methods in research, with projects dating back to the 1970 s and earlier. This article examines the integration of classics and computing, and presents a case study of EpiDoc, a markup language used in epigraphy. Positive evidence can be found for EpiDoc's influence on collaboration, with several current collaborative projects, and the nature of the technology encouraging open, reusable scholarship. The Inscriptions of Aphrodisias project illustrates much of the potential of electronic publishing. EpiDoc's effect on research questions themselves remains inconclusive, although definite possibilities for the future are apparent. Opening up these conclusions to the wider digital classics community shows a trend towards collaboration in recent publications and projects, as well as a gradual uptake of electronic publication.
\end{abstract}

\title{
Keywords
}

Electronic Libraries, Cooperation, Electronic Publishing, Classical Literature, Humanities.

\section{Introduction}

Classics as a discipline has always been one of the foremost adopters of computing technologies to support research. Roberto Busa's work with IBM on an index verborum of Thomas Aquinas, the Index Thomisticus, began in the 1940s and is arguably the first example of a 'digital humanities project', in Latin if not of an ancient writer. In the 1960s, David Packard created a concordance of Livy. In 1969, the American Philological Association appointed Stephen Waite as Supervisor of the APA Repository of Classical Texts in Machine-Readable Form which at the time contained works by approximately 22 classical authors (Brunner, 1993). This was followed by the Thesaurus Linguae Graecae (TLG) 4 in the 1970s, which is still a hugely important resource for classicists today, with over 10,000 works by 4,000 authors ("TLG - About", n.d.). Since then, digital projects in classics and the humanities more generally have expanded, building on advances in personal computing in the 1980s and the introduction of the World Wide Web in the 1990s. Today, digital methods are employed in every area of classics and much of the resulting research is being published electronically.

With technology continually improving, and a proliferation of new projects, it is necessary to inquire into the effect these digital methods are having on research. Research is limited by what is possible for researchers and the resources available to them. A glance at the history of computing shows that in the last 75 years these possibilities have changed dramatically. Electronic communication allows collaboration between geographically distant researchers, and the establishment of online communities like the Digital Classicist ${ }^{5}$ (since 2004) affords better communication and interaction online, including virtually 'attending' seminars from anywhere on the globe. There is also the opportunity for active remote participation, such as at monthly Wiki Sprints, where contributors from all over the world use shared documents, internet chat and Skype to collaboratively update the Digital Classicist Wiki (Foka, 2014). Online digital libraries such as the TLG and the Perseus Digital Library mean that students can search corpora of texts larger than they could read in a lifetime. Collaborations between classics and computer science departments have led to extraordinary research in ancient history and beyond, which would have been impossible without the use of current technology (Bevan, 2013; Gaffney, Murgatroyd, Craenen \& Theodoropoulos, 2013). In epigraphy, philology and classical literature, researchers are pushing the boundaries of electronic publication, not just online journal articles and eBooks but interactive, searchable critical editions or databases of inscriptions, openly available for use and re-use in further research (Bodard, 2008, Monella, 2008, Toufexis, 2010, Bodard \& Garcés, 2009).

Digital projects are changing research in classics: they are affecting researchers' material,

4 The TLG homepage http://stephanus.tlg.uci.edu

5 The Digital Classicist homepage http://www.digitalclassicist.org 
methods and content, and hence the questions that they are able to ask. This changing landscape has led to several retrospective and forward-looking studies of digital classics in recent years, including those by Terras (2010), Crane (2004), Babeu (2011), Bodard (2008, 2009), \& Cayless (Cayless, Roueché, Elliott \& Bodard, 2009) among others. Although they have different focuses, they highlight interoperability, infrastructure, collaboration and interdisciplinarity. Technology allows digital projects to change research, but there is a risk that it may create deeper divides between projects which duplicate work owing to a lack of common tools, standards, and infrastructure.

Classics is already a discipline covering an extensive variety of subjects: ancient history and geography, archaeology, history of art and architecture, literature, linguistics, papyrology, epigraphy, numismatics, and anthropology are just a selection. Digital methods offer the opportunity for researchers in different areas within classics to create collaborative, inter- and multi-disciplinary content. But the imperfect nature of technological development also means that these projects may often be created in their own silos of custom-made tools, leaving it to traditional-style journal articles and monographs to describe their results.

This article cannot offer a comprehensive history or assessment of digital classics projects, past and present. Instead, its purpose is to examine the ways in which digital methods are affecting research in classics, and the implications of this for future research. Improving researchers' awareness of how they work will hopefully allow them to learn from and build on previous efforts and mistakes, and present their results in ways most useful to other scholars, and most likely to survive for posterity. There are as many ways to do digital classics as there are to do traditional classics, but while manuscripts, papyri and print books can survive for hundreds or even thousands of years, electronic output is often fragile and ephemeral. We have no clear understanding about the longevity of digital artefacts. By openly examining the ways in which digital projects are changing research, researchers should be better-informed when considering how to tackle a new project in the best way.

The methodology of this study is qualitative, consisting of a literature review and case study. The literature review will cover historical accounts of digital projects within the field of classics and consider views on how digital projects are changing research methods. There will then be a section describing some of the current major digital projects in classics, highlighting some of the main methods of research and largest digital resources. This will suggest trends over time which will help to indicate the main ways in which research is changing.

The case study will consider how the use of EpiDoc aids research in epigraphy. EpiDoc ${ }^{6}$ is a set of XML standards for the markup of epigraphical inscriptions and their metadata. It forms part of a larger set of standards, the Text Encoding Initiative (TEI), ${ }^{7}$ which covers the markup of texts more generally, and which is widely but not exclusively used in the digital humanities. There are several current classics projects employing EpiDoc, which was started in 2000 by Tom Elliot, Hugh Cayless and Amy Hawkins, most notably the Inscriptions of Aphrodisias (InsAph) at King's College London, ${ }^{8}$ which aims to publish electronically several thousand inscriptions from the ancient Greek city of Aphrodisias situated in the Carian region of Anatolia (now the south-west of modern day Turkey). EpiDoc is an appropriate case study because it has now been part of the digital classics arsenal for more than 15 years; InsAph, its major pilot project, has reached substantial fruition as several electronic publications, and it is being taken up by a number of new epigraphy and papyrology projects including Inscriptions of Roman Tripolitania (IRT), ${ }^{9}$ Vindolanda Tablets Online, ${ }^{10}$ and the Papyrological Editor at Papyri.info. ${ }^{11}$ However, other methods of encoding and publishing exist in epigraphy which present alternatives to the way EpiDoc is used. The case study will be used to test

6 EpiDoc Sourceforge page http://epidoc.sourceforge.net

7 The TEI homepage http://www.tei-c.org

8 Inscriptions of Aphrodisias homepage http://insaph.kcl.ac.uk

9 Inscriptions of Roman Tripolitania homepage http://inslib.kcl.ac.uk/irt2009

10 Vindolanda Tablets Online homepage http://vindolanda.csad.ox.ac.uk

11 Papyri.info homepage http://papyri.info 
hypotheses of how research methods are changing, covering collaboration, electronic publishing, and the changing scope and content of research questions. The conclusions from the EpiDoc case study will then be widened to the Digital Classics discipline more broadly, to see how far they may be applicable, and what further evidence is available for or against them in the larger discipline.

\section{Background to Digital Projects in Classics}

\section{1 History}

One of the most detailed accounts of the early history of computing in classics is Brunner (1993), which covers the subject through the lens of developments in the American Philological Association from the 1960s to 1990. These include: the creation of their Repository of Classical Texts in Machine-Readable Form in 1969, made available on magnetic tape, the creation of the Thesaurus Linguae Graecae in the 1970s, and the growth in the 1980s of personal computing and the internet (although not the World Wide Web), allowing for communication via mailing lists. Brunner notes that in the early days, when digital projects were mostly confined to concordances of texts, most scholars regarded the computer as a time-saving device rather than a medium on which to work:

some time would pass before most humanists were able to accept the idea that the computer could provide direct access to literature, and that there was no longer any need to artificially and forcibly rearrange text in order to study and understand it.

(Brunner, 1993, p. 29)

Edmunds (1995/6) is a useful snapshot of the history of computing and classics. Written as a review of three databases/software applications, Edmunds identifies distinct phases of scholars' use of computers in their work. The first is the predominant use of computers in the 1960s and early 1970s for creating concordances and similar databases of classical texts, also identified by Brunner (1993). However, this use of computers soon changed as scholars moved from printing out the results of computer programs to working on the computer itself: "The machine was to become the site of reading and studying the machine-readable database and also the site of scholarly writing" (Edmunds, 1995/6, p. 319).

Edmunds' second phase is the rise of the personal computer, word-processing, and all the associated problems with the electronic display of Greek text at that time. Edmunds also discusses a changing way of keeping abreast of new research, with electronic aggregators like TOCS-IN: Tables of Contents of Interest to Classicists, the Database of Classical Bibliography, and L'Année Philologique. He refers to the possibility of presenting evidence differently in electronic form, creating alternative displays of epigraphical inscriptions or of texts written on scrolls. His third phase comes with the combination of hypertext and communication by computer (he was originally writing before the World Wide Web, as he notes in a postscript added in 1995). The possibilities of communication by email would, he argues, hugely aid the creation of collaborative works and of experts in different areas working together, but he worries about the issues of author credit and creating a consistent tone in the finished work.

Hardwick (2000) provides a balanced view of the effects of computers on academia and classics specifically, arguing for its impact on publishing and communicating research but also the possibility that new technology may change the nature of research itself. Hardwick suggests that in order for digital classics to flourish:

The "traditional" workplace model in which technical staff provide services to support academics is increasingly seen to be outdated and is being replaced by a more co-operative ethos in which, for example, the importance of joint technical and academic 
input on questions of design, user-friendliness and quality assurance is recognised.

(Hardwick, 2000, p. 293)

The increase in communication and collaboration, which the quote above illustrates, is particularly interesting in classics as it can apply both to scholars within different specialisms (for example epigraphers and archaeologists) but equally to classicists with technical staff and computer scientists. This is also emphasized in Terras (2010). Terras believes that good communication skills between such disparate disciplines are crucial to the success of digital classics projects, as the nature of technical work in academia is still complicated, even as new researchers and students gain technical knowledge and expertise of their own.

Ruhleder's study (1995) is important as one of only a few empirical inquiries into the changing research methods in classics, and draws on a case study of the Thesaurus Linguae Graecae (TLG), written just before the introduction of the game-changing World Wide Web. At that point the TLG was only accessible via a personal CD-ROM or an institutional copy often hosted on an intranet. After conducting 60 interviews with scholars, Ruhleder had a wealth of concrete evidence from which to draw excellent conclusions. Like Edmunds, she argues that "The gains in breadth and search scope alone are staggering when one compares the TLG to traditional tools," (p. 45) which has led to interesting results, for instance:

The graduate student writing on the word "disciple," [...] used the TLG in order to challenge the work of a senior scholar's book published forty years earlier and developed with more traditional materials.

(Ruhleder, 1995, p. 49)

The use of searchable texts such as those within the TLG was therefore having an equalizing effect on the discipline, allowing less experienced scholars and students to engage with and even challenge more senior work.

Ruhleder also discusses the way that digital projects can affect the subject of scholars' research at a more basic level:

Novel forms of data encoding change the kinds of information that are available; novel mechanisms for data manipulation change the kinds of questions that are raised. The integration of these technologies into the work process can profoundly influence work practices and organizational alliance.

(Ruhleder, 1995, p. 39)

The TLG allows scholars to search through huge corpora of texts. For example, one of Ruhleder's interviewees describes how before the TLG "You can only play out a certain number of your hunches, so you go with the best ones." (pp. 43-44) because consulting concordances and indexes, which are themselves subjective (and where the texts have been the subject of editorial interpretation), is so time-consuming. Searching an electronic database is far quicker, allowing more research questions to be considered; it also allows for the unexpected and often serendipitous search results.

However, as is often mentioned regarding the TLG, Ruhleder found classicists were frustrated by the lack of commentary and apparatus criticus, as only the texts themselves were included ( $p$. 46). In order to assess the certainty of a particular reading, scholars must consult the print versions for the commentary, and so the TLG is not capable, therefore, of replacing the need for scholarly editions of these texts. Nowadays, although it still does not include apparatus criticus or commentary, the TLG provides links to translations of texts in the Perseus Digital Library (PDL) ${ }^{12}$ and provides

12 Perseus Digital Library homepage http://www.perseus.tufts.edu/hopper 
morphological analysis from lexica with some on the TLG website and others in the PDL.

Crane (2004) is an article intended to follow on from Brunner (1993). Like Brunner, Crane also identified an early trend for producing particular concordances of works, where "standard machines were used to produce particular projects" (par. 5), but he adds three more stages of digital projects over time. Crane's second phase is that of large centralised projects, beginning in the 1970s, aiming to create infrastructure: the TLG, Bryn Mawr Classical Review ${ }^{13}$, and the Duke Databank of Documentary Papyri ${ }^{14}$. This difference from Brunner may be due to Crane's ongoing activism and considerable output on the subject of digital infrastructure for classics, and the fact that he was writing more recently than Brunner. Using computers for administrative tasks and word-processing has become so ubiquitous that it may not have seemed such a crucial stage in the history of digital classics at the time Crane was writing.

Crane's third phase agrees with Brunner's: the growth in the 1980s of personal computers allowing scholars to access much more of the available electronic resources from their offices. Crane adds a fourth phase: in the 1990s, the web, with its crucial impact on communication and the dissemination of ideas. Crane also refers to the various hardware, software and conceptual stumbling blocks of the past: computers which could display ancient Greek diacritics, bespoke hardware losing popularity in favour of open source software installed on standard personal computers, storage space restrictions receding, among others. In addition to these particular stages of development, Crane argues that classics, as a discipline, has neither the unique problems nor the budget to demand bespoke solutions, but instead classicists "must insinuate themselves within larger groups, making allies of other disciplines and sharing infrastructure" (par. 3). Many current projects in digital classics have taken this route, using methods, tools and standards from other humanities disciplines, and academia and computer science as a whole, for example Linked Open Data, wikis, crowdsourcing.

From these historical surveys, written over a period of several decades, some broad brushstrokes begin to emerge. Technology has been valuable for communication between scholars and dissemination of their research to each other and the wider world. Even in the early days of computing, technology was being used to change not only the methods of research, but the possible research questions scholars were able to choose to pursue, and the scope of their thinking. Arguably, computing is the latest in a historical and teleological progression of technologies from the introduction of writing via the codex and movable type printing to have had such an effect. The possibilities for electronic publication are expanding all the time, and collaboration between classicists, technicians, and computer scientists are necessary to build infrastructure for successful future projects.

\subsection{Overviews}

While it would be impossible to cover all of the diverse subdisciplines of classics in detail, various reports and collections have proved invaluable in giving a sense of the current landscape; in addition to Babeu's comprehensive report for the Council on Library and Information Resources (2011), there is Dunn and Mahony's The Digital Classicist 2013, as well as Bodard and Mahony's 2010 edited collection Digital Research in the study of Classical Antiquity, and their special issue of the Digital Medievalist, 'Though much is taken, much abides': Recovering antiquity through innovative digital methodologies (Bodard \& Mahony, 2008). An important addition and update to these works is the newly published Bodard and Romanello (2016) edited volume, Digital Classics Outside the EchoChamber: Teaching, Knowledge Exchange \& Public Engagement which seeks to engage audiences beyond that of the more usual classics and digital humanities scholars and practitioners. It should also be noted that, unlike many edited volumes, all those listed here have been subject to a rigorous and multiple peer review process to ensure the quality and validity of their scholarly contribution to research in this diverse area. In addition, EAGLE, the Europeana network of Ancient Greek and

13 Bryn Mawr Classical Review http://bmcr.brynmawr.edu

14 The Duke Databank of Documentary Papyri (DDbDP) http://papyri.info/docs/ddbdp 
Latin Epigraphy, ${ }_{15}^{15}$ hold regular international events and conferences, which have given rise to highquality proceedings such as Orlandi et al. (2014) and Felle and Rocco (2016), providing information on the many innovative projects combining epigraphy and digital technologies. In terms of online resources, the Digital Classicist Wiki ${ }^{16}$ and the Stoa Consortium ${ }^{17}$ provide up to date information on current projects and publications by digital classicists worldwide. There are seminar series on Digital Humanities and Digital Classics currently being run in London, Göttingen, Berlin, and New England, and abstracts, slides and video are collected on the Digital Classicist site. ${ }^{18}$ The 2015 Ancient History seminar series in Oxford was on Digital Classics, providing talks from seven prestigious researchers whose projects span prosopography, epigraphy, numismatics and digital geography. ${ }^{19}$

Babeu (2011) is a crucial piece of literature as it is a comprehensive and hugely informative overview of digital classics covering every specialism in classics and associated relevant techniques or methods in the digital humanities. Babeu identifies many themes already mentioned in the historical articles, including the growth of collaboration and interdisciplinarity, the changing notion of publishing a text, and the need to build infrastructure for digital projects of all kinds to work together.

This question of infrastructure is addressed more thoroughly in Crane and Terras (2009), a special edition of the Digital Humanities Quarterly entitled Changing the center of gravity: transforming classical studies through cyberinfrastructure. A common thread running through this special issue is that opportunities afforded to us by technology are not being taken up as fast as they are arriving: "Much as we may have achieved, we are still as a field in the incunabular phase of development, more focused upon the problems of the past than the opportunities of the present." (Crane, Seales \& Terras, 2009, p. 21). For example, digital publication allows much more than print in the way of hyperlinks, disambiguation of people and places, text recognition in Latin and Greek, integrated and interactive images and maps (Crane et al., 2009), but for most classicists "the format of our publications is essentially the same as that which Gibbon used in the 18th century" (Crane et al., 2009, p. 24). Just like Ruhleder's interviewee, Crane et al., (2009) point out that improving technologies such as searches and hyperlinked text "all reduce the time between when we pose a question and when we receive an answer. It would be hard to overstate the degree to which cost-benefit decisions, often unconscious, shape the directions that we take in our intellectual lives" (p. 59). This supports the claim that research topics are partially shaped by the possibilities of technology, and that current technology affords researchers more options than in previous decades.

As an example, the conclusion to the collection (Blackwell \& Crane, 2009) describes how electronic dictionaries and translation tools are enabling scholars and students to interact with texts in languages they cannot easily read (in this case Arabic), using electronic dictionary resources. This is confirmation of Ruhleder's findings that access to resources like the TLG levels the playing field. In addition, her and others' criticisms of the TLG's lack of apparatus criticus, commentary, scholia and so on, are being taken up as the rallying cry of those designing ideal electronic digital editions (Bodard \& Garcés, 2009, Monella, 2008 and Toufexis, 2010 among others).

\section{Current areas of research in Digital Classics}

As the previous section has already covered much of the essential earlier history of computing and classics, this section will focus on more recent developments and can only mention a small number of current initiatives; for a comprehensive and in-depth discussion, see Babeu (2011) and the Digital Classicist Wiki for updated information. The division of classics into subdisciplines in this section is only a rough guide to areas of digital development; most of the projects mentioned span

15 EAGLE homepage http://www.eagle-network.eu

16 The Digital Classicist Wiki homepage https://wiki.digitalclassicist.org

17 The Stoa Consortium homepage http://www.stoa.org

18 The Digital Classicist: Seminars http://www.digitalclassicist.org/wip

19 Oxford Ancient History Seminar, Spring Term 2015 http://users.ox.ac.uk/ corp1223/DigitalClassics.htm

Panta Rei (2016), 125 - 148 
several areas of classics and some are collaborations with other academic departments such as computer science.

In archaeology, Silchester Roman Town Life ${ }^{20}$ is one of the most prominent digital projects which have incorporated digital technology into mapping and reconstructing digs, and creating databases of finds to make available online, sharing them with the rest of the community. It has updated the existing Integrated Archaeological Database (IADB) from a MS Access database to a web application using MySQL and PHP, recording images and details of the archaeological records as well as plans of the dig. The project also experimented with digital methods of recording on site, with digital pens and optical character recognition (OCR) in an attempt to minimise the effort of digitising and uploading the information at a later stage of the process. The results of this project have included vital feedback on the various tools trialled, and several high quality electronic publications using the IADB information, including one on the Victorian Excavations of 1893 (Clarke, Fulford, Rains, \& Shaffrey, 2001). Fulford, O'Riordan, Clarke, and Rains (2010) is an overview of the project's history and findings.

Ancient geography and mapping has been a very fruitful area for digital projects. The bestknown is Pleiades, ${ }^{21}$ which began as an online edition of the Barrington Atlas of the Greek and Roman World (Talbert, 2000), and has now expanded to include (at the time of writing) nearly 35,000 ancient places and 38,700 ancient locations, thanks largely to volunteer contributions. Pleiades fulfils a crucial role in digital classics by providing stable links (uniform resource identifiers, or URIs) for each of the places attested, which can then be used by other resources for disambiguation. These other resources can in turn enrich Pleiades by using linked data to add content about places, for example as InsAph does (Elliot, 2012). All the information in Pleiades is released under Creative Commons Attribution 3.0 License (cc-by), allowing reuse and derivatives as long as appropriate credit is given ("Creative Commons", n.d.). Pleiades also provides visualisations in the form of interactive maps, but arguably its greatest impact has been the stable URIs, creating infrastructure for further interoperability and communication between projects. In this way, it fulfils a similar role for the study of the ancient world that GeoNames ${ }^{22}$ fulfils for other projects in the digital humanities. Much of the linked data infrastructure used to connect Pleiades to other resources is facilitated or created by a project named Pelagios, ${ }^{23}$ which is becoming increasingly useful as more resources take on their annotation model of marking up place names using Pleiades URIs and Pelagios ontologies. A succinct description of their work so far is at Isaksen et al. (2014). More recently, the Pelagios project has entered a new phase of funding to develop Pelagios Commons, which attempts to support the growing community of scholars and technicians interested in creating Linked Open Data in classics. This is facilitated via Special Interest Groups (SIGs), as well as Pelagios' previously-developed tools for semi-automatic tagging and disambiguating historical place names in texts (Recogito ${ }^{24}$ ) and mapbased searching of annotations (Peripleo ${ }^{25}$ ).

There are many other projects that to some extent incorporate mapping or visualising digital geography. The Hestia project ${ }^{26}$ has done work on mapping places mentioned in Herodotus' Histories, which has produced interesting findings for research. For more information on both Hestia and Pelagios, see Barker (2015) and Dunn and Mahony (2013). Some of the researchers involved in Hestia have also been responsible for Google Ancient Places, ${ }^{27}$ which is investigating automated methods of tagging online resources like Google Books with annotations of Pleiades URIs for any

20 Silchester Roman Town homepage http://www.reading.ac.uk/silchester

21 Pleiades homepage http://pleiades.stoa.org

22 GeoNames homepage http://www.geonames.org

23 Pelagios homepage http://commons.pelagios.org

24 Recogito homepage http://pelagios.org/recogito

25 Peripleo homepage http://pelagios.org/peripleo/map

26 Hestia project homepage http://hestia.open.ac.uk

27 Google Ancient Places Wordpress site https://googleancientplaces.wordpress.com 
locations mentioned.

Another area of digital classics which is exploring linked data is online prosopographies. A prosopography is a structured collection of biographical information about individuals although often only where names are mentioned without any further details. These can be restricted to a geographical location, a time period, or an occupation (for example library catalogue authority lists). In classics, a few large online ones are the Lexicon of Greek Personal Names (LGPN), ${ }^{28}$ the Prosopography of the Byzantine World (PBW), ${ }^{29}$ and the electronic edition of the Prosopographia Imperii Romani (PIR). ${ }^{30}$ These each attempt to disambiguate, as far as possible, and with their own standards, the identities of and connections between individuals from the Classical and Byzantine worlds. In addition to dedicated prosopographies, many other digital projects provide databases of persons, particularly projects in epigraphy, papyrology, or manuscript studies, where researchers are dealing with texts which include named individuals. For example, one of several aims of the Trismegistos project ${ }^{31}$ is to disambiguate people and places in its papyrological and epigraphic resources.

With the emergence of these disparate online sources for prosopographical data, a project has begun to provide a linked data infrastructure for linking between them and creating stable URIs for them, much as Pleiades does for ancient places. This project is SNAP:DRGN, Standards for Networking Ancient Prosopographies: Data and Relations in Greco-roman Names. ${ }^{32}$ Although (at the time of writing) still in its early stages, it is currently working with Trismegistos, LGPN, PIR and the Epigraphische Datenbank Heidelberg (EDH), among others, developing linked data ontologies for the individuals mentioned. SNAP is also creating workflows and tools for other projects to contribute people records, so that this open, growing, network of information can be enriched by new research.

For those studying classical literature, there are various important online sources of material. The Thesaurus Linguae Graecae ${ }^{33}$ is one of the oldest digital libraries of classical texts, and has been discussed in the previous section. It provides access to the texts themselves, based upon a chosen print edition, with morphological tools and links to translations, but without commentary or apparatus criticus. For Latin, there is the Packard Humanities Institute Latin library ${ }^{34}$ and the Thesaurus Linguae Latinae. ${ }^{35}$ The Perseus Digital Library (PDL) ${ }^{36}$ is another vast digital library of both literary and historical texts and images of archaeological artefacts. In addition to the texts, which are encoded using XML, PDL provides sophisticated linguistic hyperlinking to online dictionaries, morphological tools, and English editions of the text, allowing readers to see translations and crossreferences to other texts in the library. In 2013, the University of Leipzig's Open Philology Project began collaborating with the PDL, and one of its current initiatives, the Open Greek and Latin Project ${ }^{37}$ aims to produce online version of every text in Ancient Greek or Latin, including manuscripts, papyri, and printed texts from antiquity until the present.

There is much ongoing discussion of the best ways to put together digital critical editions, as the expert commentary, translation, and apparatus criticus is often something missing from many large digital libraries. Bodard and Garcés (2009) discusses some of the potential advantages of creating critical editions online, including the possibility for greater collaboration on an equal basis between newer and more established researchers. More recently the UCL Centre for Digital Humanities has had a doctoral student working on creating a digital edition of Saint Augustine's De Civitate Dei who

28 Lexicon of Greek Personal Names homepage http://www.lgpn.ox.ac.uk

29 Prosopography of the Byzantine World homepage http://blog.pbw.cch.kcl.ac.uk

30 Prosopographia Imperii Romani homepage http://pir.bbaw.de

31 Trismegistos homepage http://www.trismegistos.org

32 SNAP:DRGN homepage http://snapdrgn.net

33 TLG homepage http://stephanus.tlg.uci.edu

$34 \mathrm{PHI}$ Latin texts homepage http://latin.packhum.org

35 TLL homepage http://www.thesaurus.badw-muenchen.de

36 Perseus Digital Library homepage http://www.perseus.tufts.edu/hopper

37 Open Greek and Latin Project homepage http://www.dh.uni-leipzig.de/wo/projects/open-greek-and-latinproject 
as part of the background research for this project has created a catalogue of extant digital editions to investigate best practice and what is needed to make a good and useful critical edition of an ancient text (Franzini, Terras \& Mahony, 2016). The Homer Multitext Project ${ }^{38}$ has conducted hugely useful work in developing the Canonical Text Services and CITE architecture, a framework for citing digital versions of texts effectively (Smith, 2010). Paolo Monella has written about the process of creating an XML-encoded digital edition including "interlinear annotations, glosses, scholia, footnotes, modern scholarly introductions and commentaries, and many others" (Monella, 2008, abstract). This involves deciding on a complex tree of texts and 'paratexts' which comment upon it, and uses hyperlinks to refer the annotations to the correct portions of the text. Of course, the challenges and advantages of bringing manuscript studies online is one shared by the whole digital humanities community, and many online resources of medieval manuscripts are also of interest to classicists.

Two projects treated in Dunn and Mahony (2013) are of particular interest as collaborations between computer science and classics, and are especially innovative approaches to studying ancient history. Bevan (2013) describes a project that uses archaeological evidence and computational modelling to try and postulate ancient societies' patterns of movement and travel. This is an exciting idea for using existing computer modelling techniques to apply to ancient history and could possibly provide theories about ancient trade routes. Gaffney, Murgatroyd, Craenen and Theodoropoulos (2013) and Murgatroyd, Craenen, Theodoropoulos, Gaffney and Haldo (2011) describe a collaborative project using agent-based modelling to try and simulate the large-scale military expedition of the Byzantine army to the battle of Manzikert in AD 1071. Again, it is an example of applying computer science methods to a historical event, creating hypotheses which can be tested against archaeological and literary records.

In numismatics, work is being done to bring together online resources about ancient coins, as data is often scattered across museum catalogues and commercial auction sites as well as academic sources. Heath (2010) describes preliminary work in scoping out potential sources of data among these commercial sites. Nomisma.org ${ }^{39}$ is a project using linked data, including that created by Pelagios, to create useful ontologies and stable URIs for referring to coins and related concepts online. Again, the focus is on building online infrastructure so that researchers can access as much of the available information as possible and add to it with their own findings. Gruber, Bransbourg, Heath and Meadows (2013) go into more technical detail in their conference paper explaining the linked data approach of Nomisma.org.

In epigraphy and papyrology, digital projects often have to deal with the challenge of the subject of their research being both a text (inscribed or handwritten) and a physical object. As well as large digital libraries of inscriptions and papyri, there is now a growing number of aggregating projects and consortia, which aim to improve cross-searching between resources. In papyrology, the largest is Papyri.info, ${ }^{40}$ which comprises both the Papyrological Navigator for searching texts, and the Papyrological Editor for editing them. User contributions are peer-reviewed. Currently Papyri.info collects information from the Advanced Papyrological Information System (APIS), Duke Databank of Documentary Papyri (DDbDP), Heidelberger Gesamtverzeichnis der griechischen Papyrusurkunden Ägyptens (HGV) and Bibliographie Papyrologique (BP). It also works with Trismegistos, mentioned above, which aims to provide stable URIs for disambiguating people and places mentioned in its sources. Baumann (2013) is a source of more detailed and technical information on Papyri.info.

The Ancient Lives project hosted by Zooniverse ${ }^{41}$ is an example of crowdsourcing transcriptions of the Oxyrhynchus papyri, allowing volunteers to create transcriptions from images of the texts. Crowdsourcing is a technique employed throughout the digital humanities, particularly for

38 Homer Multitext Project homepage http://www.homermultitext.org

39 Nomisma.org homepage http://nomisma.org

40 Papyri.info homepage http://papyri.info

41 Ancient Lives homepage http://www.ancientlives.org 
transcriptions, as well as library, museum, local history, and citizen science projects. ${ }^{42}$ The largest and earliest crowdsourcing project in classics is the Suda On Line, ${ }^{43}$ an electronic edition of the $10^{\text {th }}$-century Byzantine Greek historical encyclopedia which anyone can help to edit, translate and annotate.

In epigraphy, a similar consortium to Papyri.info is EAGLE, the Europeana Network of Ancient Greek and Latin Epigraphy. ${ }^{44}$ It currently comprises the Epigraphische Datenbank Heidelberg (EDH), the Epigraphic Database Roma (EDR), the Epigraphic Database Bari (EDB) and Hispania Epigraphica $(\mathrm{HE})$. It aims to provide cross-searching across these extensive databases of inscriptions, as well as working with other projects like Trismegistos and Papyri.info to continue to create infrastructure for epigraphy and papyrology. A newer project, Integrating Digital Epigraphies (IDEs), ${ }^{45}$ at Duke University, aims to fulfil a similar purpose to Papyri.info, but with a difference: they will not own or centrally host the data they are providing. The individual partners will continue to control their own data, and IDEs hopes to be able to include searching of non-classical sources such as JSTOR, and non-academic ones like Flickr. For more information, see Cayless (2015) and Löser (2014/15).

The directions taken by digital classics projects are as varied as their subject matter, and there are many more ongoing and completed than have been mentioned here. However, there is a relatively recent trend of building infrastructure within and between subdisciplines. Now that there are often many independent projects on any given subject, there are growing consortia aiming to bring these projects together, either by taking over their hosting, or providing ways of linking and cross-searching. This is happening in papyrology, epigraphy, numismatics, manuscript studies and elsewhere. This is often achieved through the use of sharable Linked Open Data. ${ }^{46}$ EpiDoc, the case study dealt with in the next section, is one way in which projects can aim to be interoperable, by adopting the same standards, and so benefit from this infrastructure.

\section{Case study}

\subsection{Hypotheses}

From the sections above, several broad trends emerge concerning how digital projects might be affecting research methods in classics. The hypotheses that will be tested by the EpiDoc case study that follows are limited by space and scope, and cannot cover all that is suggested by the historical background and current areas of research. However, they are chosen to be representative and they are:

a) That digital methods are improving opportunities for collaboration

b) That digital methods are providing new and useful means of publication for research

c) That digital methods are increasing the possible scope and content of research questions

This case study will consider how far the EpiDoc projects support these hypotheses, and discuss other ways in which they may be changing research methods in classics.

\subsection{EpiDoc}

Epigraphy is a subdiscipline in classics which studies texts inscribed on stone, wood, metal, clay, and other hard materials. These inscriptions may vary widely in content and context, some

42 See for example The Transcribe Bentham project at UCLDH http://blogs.ucl.ac.uk/transcribe-bentham

43 Suda On Line homepage http://www.stoa.org/sol

44 EAGLE homepage http://www.eagle-network.eu

45 IDEs homepage http://blogs.library.duke.edu/dcthree/projects

46 For more on Linked Open Data see http://linkeddata.org 
being official records or accounts of ruling families, but also labels on pots, signs, or funerary objects. As Feraudi-Gruénais (2010, p. 2) puts it, epigraphers study "everything that is scratched, chiselled or in any way written on a hard object [...] there were inscriptions, whether small or large, scratched or engraved, for all eventualities in life." They are rarely, however, texts studied as literature, thus setting epigraphers apart from literary scholars. And although the media on which they are carved may be separately interesting to archaeologists or historians, the texts themselves are often not considered in any depth by these researchers. Epigraphy, then, is an area of classics which has great potential to benefit from digital methods encouraging collaboration with other scholars in archaeology, philology or elsewhere, given that classics has, as Bodard puts it, "tended to keep inscriptions in an academic limbo-not quite literary text and not quite archaeological object. They have rarely received the attention they deserve either from philologists or material culture specialists." (Bodard, 2008, §2).

By the $20^{\text {th }}$ century, scholars were producing print editions of corpora of inscriptions, often organized by geographic location, time period, or theme. These authors needed to find ways to explain their transcriptions: where there were missing letters, or where the editor had restored what they thought were the correct letters, or there was uncertainty over the text, and so on. Usually each edition would have a list of epigraphic conventions at the beginning of the book, but they weren't yet standardised (Bodard, 2010). With changing approaches to publication, such as the Corpus Inscriptionum Latinarum (CIL), an extensive collection of Latin inscriptions whose first volume appeared in 1853, the need for a universal standard became more pressing (see Cayless et al., 2009, par. 9). In 1931, a convention was held in Leiden which drew up standards for the epigraphic community to use from then on. The main features of the Leiden conventions are: the use of square brackets around text which is missing from the object and which has been restored by the editor, parentheses around expansions of abbreviations, and underdots on letters which cannot be clearly read. For more details and examples, see Cayless et al. (2009, pars. 9-11).

The earliest digital projects relating to epigraphy include Packard Humanities Institute's Greek Epigraphy project (PHI-GE $)^{47}$ and the Epigraphische Datenbank Heidelberg (EDH), ${ }^{48}$ set up in the 1980s. These databases and many others chose to transcribe inscriptions directly from print editions, retaining as much of the original Leiden conventions as possible. Some removed symbols like the underdots which were difficult to encode on computers of the time, or started using different symbols for this purpose. This decision to keep the Leiden conventions as part of the transcriptions continues today, as EDH was one of the first three databases to make up EAGLE, the Electronic Archive of Greek and Latin Epigraphy. ${ }^{49}$ The PHI-GE and the Thesaurus Linguae Graecae chose to use what was a special encoding at that time called Beta Code for rendering accented Greek and also including symbols for the Leiden conventions. But Beta Code requires special software to display properly, whereas nowadays Unicode has been widely accepted and displays more consistently in web browsers (see Bodard, 2010 and EpiDoc's Digital Classicist Wiki page). ${ }^{50}$

In 1999 there was a round-table meeting by the commission on Epigraphy and Information Technology which discussed standards for planned databases of epigraphy. It was agreed that these databases needed to use Unicode and XML (Cayless et al., 2009, pars. 14-16). It was at this point that Tom Elliott, working at the University of North Carolina at Chapel Hill, agreed to publish online his work so far on using XML for epigraphy. As Cayless et al. explain (2009, pars. 16-18), the early days of the EpiDoc guidelines were a collaboration between many researchers at Chapel Hill, and the first draft was published via the Stoa Consortium in 2001 with the help of Ross Scaife, Anne Mahoney, John Bodel and Charles Crowther. Charlotte Roueché at Kings College London then became involved, receiving funding from the Leverhulme Trust to run an EpiDoc-Aphrodisias Pilot

\footnotetext{
47 Packard Humanities Institute - Greek Epigraphy homepage http://epigraphy.packhum.org/inscriptions

48 Epigraphic Database Heidelberg homepage http://edh-www.adw.uni-heidelberg.de/home

49 Europeana EAGLE project homepage http://www.eagle-network.eu

50 EpiDoc on The Digital Classicist Wiki https://wiki.digitalclassicist.org/Epidoc
} 
Project, which became the Inscriptions of Aphrodisias (InsAph). ${ }^{51}$ This project has since led to two online publications: a second edition of Roueché (1989) in 2004, and an edition of all the inscriptions up to 1994 with commentary (Reynolds, Roueché \& Bodard, 2007). Since InsAph, several other projects have taken up EpiDoc, including Inscriptions of Roman Tripolitania ${ }^{52}$ and Inscriptions of Roman Cyrenaica, ${ }^{53}$ both being developed and worked on by the same team as InsAph. Another project currently being undertaken using EpiDoc is the US Epigraphy Project, ${ }^{54}$ which has existed since 1995 and been hosted by Brown University since 2003. It includes approximately 2,500 Greek and Latin inscriptions preserved in the USA, with (to date) 400 encoded using EpiDoc, as well as 1000 accompanying images.

The purpose of EpiDoc is to allow epigraphic inscriptions to be encoded in XML, Extensible Markup Language, an open source meta-language maintained by the World Wide Web Consortium ${ }^{55}$ that is used to store and encode structured text. EpiDoc is a subset of the TEI, the Text Encoding Initiative,$^{56}$ which is a broader-purpose set of guidelines aimed at standardising the encoding of any kind of text documents in XML, making them structured and machine readable. The TEI is widely, although not exclusively, used in the digital humanities (Franzini et al., 2016). EpiDoc does not replace the Leiden conventions used in print, but aims to make those conventions machine-readable and incorporate their structure into the document. Instead of having a text file with the Leiden conventions as written, with characters such as square brackets and underdots, EpiDoc replaces these with elements (for example <supplied $><$ /supplied $>$ ) surrounding the affected text. This makes it more verbose when editing (see Figure 1), but adds true structure to the digital representation of the inscription, allowing for the inclusion of additional information, much more flexible searching, and alternative display options rather than just including the conventions in the transcriptions as Unicode characters.

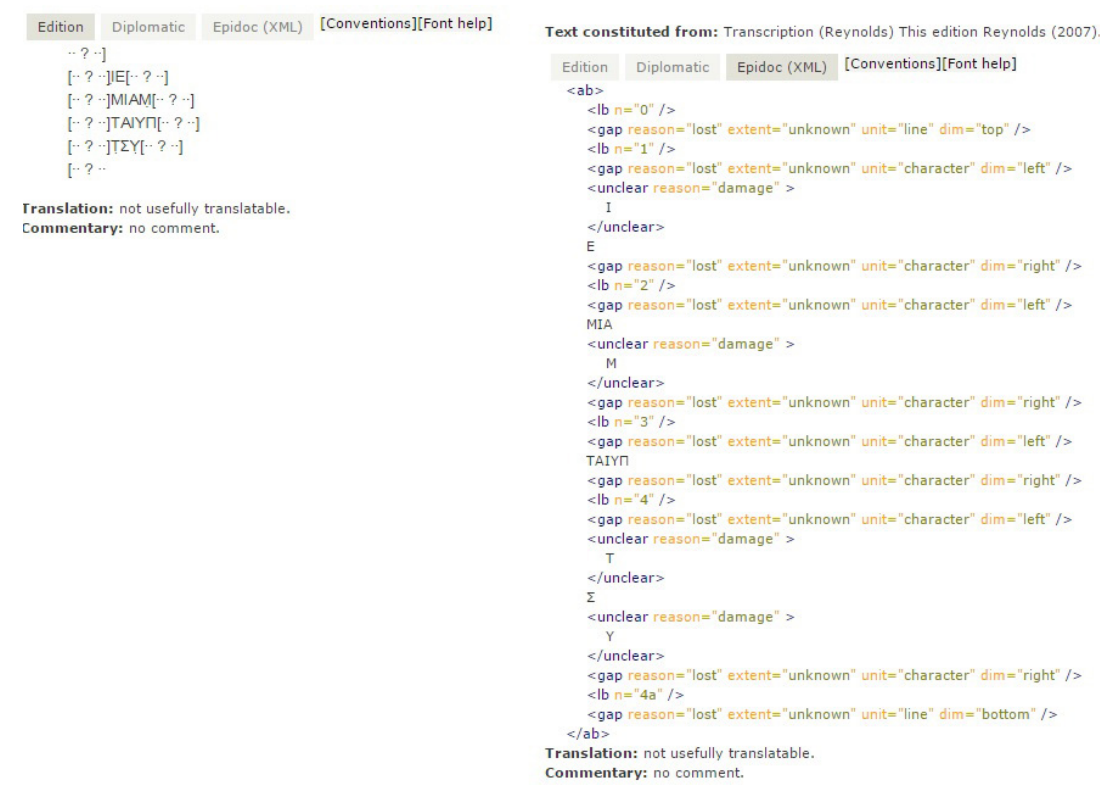

Figure 1: The marked-up transcription of IAph2007 11.14 (left), compared with the XML source (right). ${ }^{57}$

51 Inscriptions of Aphrodisias homepage http://insaph.kcl.ac.uk

52 Inscriptions of Roman Tripolitania homepage http://inslib.kcl.ac.uk/irt2009

53 Inscriptions of Roman Cyrenaica homepage http://www.ircyr.kcl.ac.uk

54 U.S. Epigraphy Project homepage http://usepigraphy.brown.edu/projects/usep/about

55 W3C homepage http://www.w3.org/XML

56 The TEl homepage http://www.tei-c.org

57 Inscriptions of Aphrodisias, Inscription 11.14 http://insaph.kcl.ac.uk/iaph2007/iAph110014.html 
For example, assuming a comprehensive markup, it is possible to search for a name and find abbreviated versions of it as well as where it is written in full, because in EpiDoc you can include the full name as well as the abbreviation. It is also possible to display inscriptions in different ways without having to duplicate the information: different outputs to display the content in a variety of ways can be generated by using XSLT (Extensible Stylesheet Language for Transformations) stylesheets. Using an appropriate stylesheet, one could for example create a 'diplomatic version' of the text (see Figure 2), where transcriptions only showed the letters the editor could read with certainty, exactly as they are on the object as well as an edited version which would include the editor's interpretation.
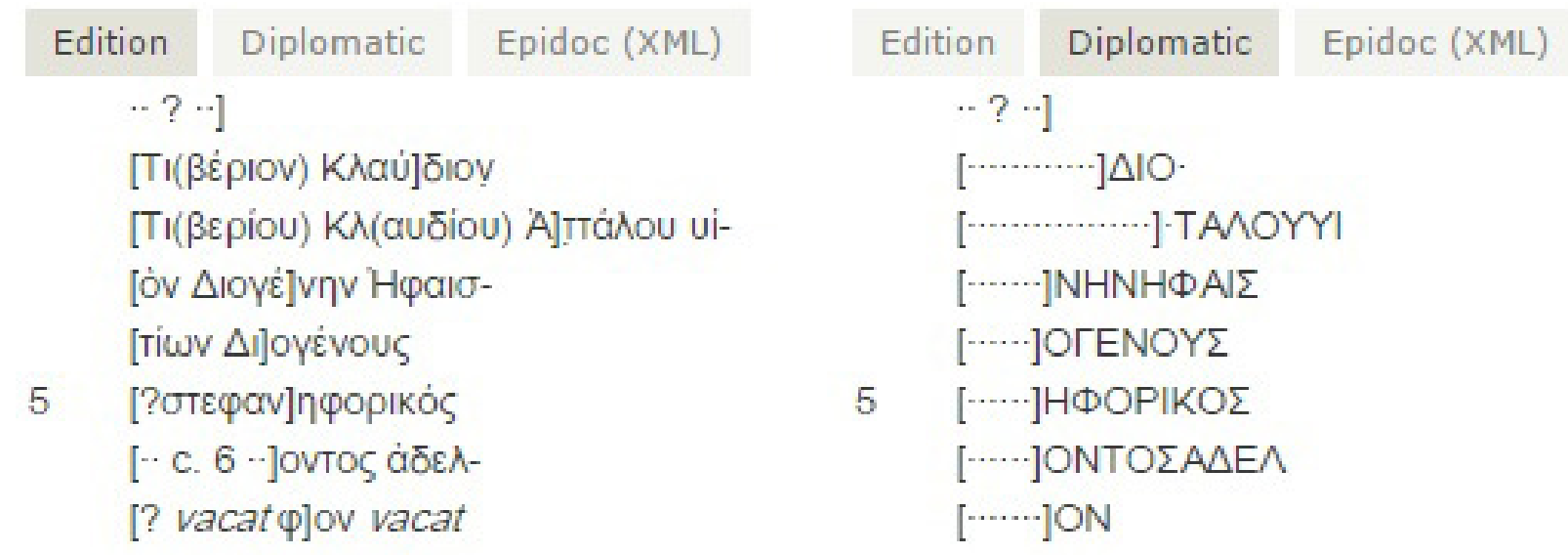

Figure 2: The marked-up transcription of IAph2007 11.15 (left), compared with the diplomatic transcription (right). ${ }^{58}$

Or one could search for all possible abbreviations of a name like Augustus, something not possible without some markup to indicate where an abbreviation occurs and what it is an abbreviation of. For worked examples of translating Leiden to EpiDoc, see Bodard (2010) and Cayless et al. (2009, pars. 9-19). Finally, although all aspects of the Leiden conventions map onto EpiDoc elements, there is also functionality for including extensive metadata, such as archaeological details of the objects, geographical locations and findspots, and prosopographical information to disambiguate people mentioned. This functionality is discussed further in Tupman (2010). Not every project needs to use all of the available elements, but there is the potential for a lot more information about the inscriptions to be included by researchers in different areas of classics.

Some of the first aims of the Chapel Hill team were to develop tools which they would release along with guidelines to enable scholars to use EpiDoc more effectively. These included a tool for converting text files of transcriptions with Leiden conventions into marked-up EpiDoc inscriptions, called CHET-C (Chapel Hill Epigraphic Text Converter), which was already developed in 2003 when Cayless gave a talk at the ALLC/ACH Joint International Conference (2003). On the EpiDoc SourceForge page ${ }^{59}$ there are also sample stylesheets for displaying the inscriptions and various community-developed tools. Some of these tools allow 'crosswalking', converting between different standards for describing editions of texts. For example, it is possible to convert Inscriptions of Roman Tripolitania EpiDoc inscriptions to the standards used by Epigraphische Datenbank Heidelberg.

58 Inscriptions of Aphrodisias, Inscription 11.15 http://insaph.kcl.ac.uk/iaph2007/iAph110015.html 59 EpiDoc Sourceforge page http://sourceforge.net/p/epidoc/wiki/Home 
Impressively, Papyri.info converts its three contributing databases of inscriptions (DDbDP , HGV and APIS) into EpiDoc, in a lossless and reversible process (Bodard, 2010; Elliott et al., 2007-2016).

\subsection{Testing Hypotheses}

\section{a. That digital methods are improving opportunities for collaboration}

The EpiDoc guidelines are, and have always been, a collaborative effort. Elliott worked with others at Chapel Hill in developing them and they have been iteratively improved as a result of the pilot project InsAph, and continue to be influenced by the work being undertaken by the US Epigraphy Project and others. There have also been extensive discussions on the Markup mailing list, ${ }^{60}$ raising issues, discussing potential improvements and working collaboratively on EpiDoc itself. The early stages of putting together the guidelines was also helped by several AHRC funded workshops, so that 'Its scope has expanded beyond (though not abandoned) the original vision for a common interchange format. EpiDoc now aims also to be a mechanism for the creation of complete digital epigraphic editions and corpora' (Cayless et al., 2009, par. 18). All EpiDoc resources, including the toolkit mentioned above, customisation information and the guidelines itself are available for anyone to download and use under the GNU General Public License. ${ }^{61}$ The creation of EpiDoc itself, therefore, is clearly collaborative. But what of its influence on collaboration in classics research more widely?

One of the possibilities of InsAph, as described in Bodard (2008), is that its contents can be reused: the inscriptions are available to be downloaded freely under the Creative Commons attribution licence. This means that the data from InsAph "may be downloaded en masse and incorporated into a larger project; an epigraphic corpus, say, or a more general collection of Greek and Latin texts, or a specialist corpus of texts relating to the provincial Roman economy." (Bodard, 2008, §28). This open scholarship approach is one shared by many other epigraphic and digital classics projects generally, and is a move away from the restrictive owning of data encouraged by traditional print publications. It is also enshrined in the free distribution of the EpiDoc guidelines and source code themselves. However, although open access and open data are encouraged, the terms of the Creative Commons licence do not prohibit researchers from choosing to use EpiDoc in creating subscription-access resources if they wish.

Examples of collaboration between different online classics projects as a result of EpiDoc already exist. Blanke, Hedges and Rajbhandari (2013) describe work on creating a Virtual Data Centre for Classics, which takes the InsAph transcriptions and combines them with those of the Heidelberg Gesamtverzeichnis der griechische Papyrusurkunden Ägyptens (HGV) ${ }^{62}$ and Projet Volterra. ${ }^{63}$ These other projects do not use EpiDoc themselves, but EpiDoc's openness encourages their combination with InsAph's.

EpiDoc has also been used by the Integrating Digital Papyrology project ${ }^{64}$ to create a common search interface for three papyrological resources: the Duke Databank of Documentary Papyri (DDbDP), the HGV and the Advanced Papyrological Information System. This project used tools to convert DDbDP transcriptions to EpiDoc, for more information see Baumann (2013). Papyri.info is now a major papyrological digital resource, and its use of EpiDoc has been crucial for designing the editing interface and combining the data from these different sources to allow cross-searching.

As alluded to above, EpiDoc has the potential to encourage collaboration between epigraphers

60 Markup mailing list archive http://lsv.uky.edu/archives/markup.html

$61 \mathrm{GNU}$ Licenses http://www.gnu.org/licenses/licenses.html

62 Heidelberger Gesamtverzeichnis der griechischen Papyrusurkunden Ägyptens homepage http://www. rzuser.uni-heidelberg.de/ gv0

63 Projet Volterra homepage https://www.ucl.ac.uk/volterra

64 IDP's Papyri.info homepage http://papyri.info/ 
and other classicists, for example archaeologists. Tupman (2010) discusses in detail the possibilities of using EpiDoc for inscriptions on funerary items, explaining that different scholars' expertise often leads to inscriptions becoming divorced from information about their origins.

It is unlikely that one person would acquire sufficient knowledge of each type of material evidence to be able to analyse and publish all of it with equal depth and understanding [...] Specialists, therefore, need to work to make their material available to others in a way that permits their various forms of data to be combined meaningfully.

(Tupman, 2010, p. 77)

With the digital publication of inscriptions, it would be possible for each of these experts to add to the information without having to work directly with each other, but they would have to be willing to collaborate, sharing credit and taking decisions on future publications together. Tupman (2010) is mildly sceptical about this proposition: "There appears still to be a scholarly possessiveness that, upon occasion, curtails attempts to work collaboratively; and an extension of this is anxiety over putting material online where 'anyone can use it'." (p. 85) Other potential pitfalls for collaboration between scholars in different departments are discussed in Terras (2010): the need for effective communication between classicists and computer scientists, tensions about where to publish results of projects and how to order author names, insufficient credit being awarded to scholars who produce digital editions rather than print monographs, difficulties in finding funding, and extra training needed for students wanting to help but lacking in technical expertise.

A major part of EpiDoc's appeal is that the more projects that take it up, the greater the potential for collaboration. This is what is argued in Cayless et al. (2009), and there has been some take-up of it in projects using EpiDoc and InsAph for new purposes, such as Papyri.info. The process of improving and changing the EpiDoc guidelines is certainly highly collaborative, and its open-source nature affords opportunities for new researchers to use the inscriptions for their own work. But as Tupman and Terras point out, collaboration is a human business, and it relies on scholars and the academic community more widely to provide suitable opportunities and recognition for collaborative work in digital classics.

\section{b. That digital methods are providing new and useful means of publication for research}

The advantages of digital publication over print for epigraphy are discussed in detail in both Bodard (2008) and Tupman (2010). Inscriptions have often been collected in print volumes by geographical location (as with the Corpus Inscriptionum Latinarum), time period, language, theme, or a combination of these. They commonly feature the text of the inscription, along with editorial additions, some information about the object the inscription is on, details of its discovery, any editorial commentary, and possibly a bibliography of works where the inscription is cited. What is rarer in print volumes is the use of significant numbers of images, mainly for printing expense reasons, and also, as Tupman suggests (2010, p. 75$)$, "the traditional prioritization of text over image".

This is something that digital publications frequently improve upon: due to the availability of storage space for most universities, electronic epigraphic publications can include many more photographs, in colour and at a high quality, of the texts than would be possible in a print publication (for example, InsAph item ala2004 53 has multiple greyscale and one colour photo of the same artefact). ${ }^{65}$ Further, in this example it is clear to see the object on which the text is inscribed as well as some of the context as opposed to the simple flat image of the inscribed text that appears in the print publication (Roueché, 1989 Aphrodisias in Late Antiquity plate xiii). This is a simple but often-mentioned advantage of electronic publication, and is by no means restricted to epigraphy: papyrology, archaeology, art history and other areas of classics all benefit from the affordances of

65 Roueché, 2004, inscription 53 http://insaph.kcl.ac.uk/ala2004/inscription/eAla053.html 
digital publication. Perseus Digital Library, as well as containing over 68 million words of classical texts, also stores images of more than 6000 art and archaeological objects ("Perseus Collections/ Texts", n.d.).

Similar is the ability to remove the limitations of space applied to print volumes (see Bodard, $2003, \S \S 17-19)$. There is no longer the need to use abbreviations when describing inscriptions. Or if the editors want to keep standard abbreviations, there is no difficulty in including a glossary for the uninitiated, which can be hyperlinked to the relevant terms. This could enable a new reader to hover over a word or acronym they do not understand, and be informed what it means, while a different researcher can read unimpeded.

This leads to the further possible uses of hyperlinks in electronic publication, prominently featured in Edmunds (1995/6) and no less important today. Given that print epigraphic corpora often include bibliographic information, this can continue in digital editions by linking to any openly available online publications. Further, it would be possible in the future for epigraphers to link their inscriptions with prosopographical online projects like SNAP:DRGN, allowing disambiguation of people, or with online gazetteers like Pleiades, allowing disambiguation and visualization of ancient places. This mapping is already being implemented for the Inscriptions of Roman Tripolitania. Internal hyperlinks are also crucial for linking together commentary and the inscriptions themselves, as already illustrated in Roueché (2004).

Projects using EpiDoc currently publish their work freely on the internet under Creative Commons licences. This, as Bodard $(2008, \S \S 14-16)$ points out, allows greater accessibility to universities than expensive print volumes, particularly as epigraphy is a small subdiscipline of wider classics. This is especially true for less well-funded and connected academic communities as well as researchers and students in less wealthy institutions and countries. It is not assured that all projects using EpiDoc will publish their results openly; many electronic academic publications already take a paid subscription route.

In terms of accessibility, EpiDoc also allows for considerably more flexibility in how material is displayed. Once marked-up the content is separate from its appearance, unlike a print book, so it is possible to display it differently for different purposes without having to duplicate the work.

Using a slightly different set of stylesheets, one might present the same data in PDF for more convenient printing, or even a whole typeset volume that can be ordered and printed on demand. The standard, interpretive Leiden transcriptions may be augmented with parallel diplomatic versions [...] Slightly different versions might also be designed for students, with more emphasis given to the translation and historical commentary [...] Stylesheets may also transform the same text into an audio version for the visually impaired

(Bodard, 2010, pp. 110-11)

The possibilities are vast, and of course there is the ability to search and sort inscriptions dynamically in a way completely impossible for a print volume. Currently, Reynolds et al. (2007) provides each inscription page with views of the full Leiden version, a diplomatic version, and the EpiDoc XML, as well as images and the option to download the XML and DTD. However, the full potential of electronic publication of EpiDoc projects is yet to be realised, possibly because of the technical expertise and time required to produce these different displays over and above the scholarly research.

Another feature of electronic publication is the ability to update and add to the corpus without a fixed end-point. This can be an advantage: completed research can be published while other parts are still in progress, mistakes easily corrected, addendum and corrigendum now become part of the document rather than requiring a re-print or corrections in a letter included with the print volume. But this may conflict with the finite time and funding of most projects. Scholars will need to take on new projects, and cannot indefinitely make improvements to older work: this is why InsAph's output 
is divided into two static electronic publications. Of course, it is an advantage of digital publication that the project can later be improved by further funding, or by being downloaded and used on other projects elsewhere in a way impossible for print publications. Papyri.info have faced this challenge by allowing volunteers to add and edit their resources with peer-review for quality control, knowing that their publication will always therefore be 'in progress' to some extent (Baumann, 2013). Another project harnessing crowdsourcing is Perseids, ${ }^{66}$ run from within the Perseus Digital Library (PDL), which is investigating the pedagogical and scholarly potential of volunteer contributions in annotating texts and creating digital editions of ancient texts. From Almas and Beaulieu (2016) it is possible to conclude that the ability for teachers and students to use available tools to collaborate and create small (or large) corpora of original work is of value, both in changing the way classical languages and texts are often taught, and as scholarship in its own right. The fact that the high-quality work achieved by undergraduates can be published via PDL, and made available for reuse, rather than simply being assessed within the institution and then discarded, is another positive feature. Dee et al. (2016) and Bodard \& Stoyanova (2016) also discuss the pedagogical value and potential pitfalls of learning to use the EpiDoc guidelines themselves. They highlight the increased longevity of work created by teaching exercises, and the positive contributions of interpersonal support via mailing lists and other resources, as well as the similarities between encoding texts in EpiDoc and traditional methods of creating a digital edition.

It is clear that electronic publication has huge potential advantages over print, and EpiDoc projects such as InsAph are a great example of some of these possibilities being put into practice: hyperlinking, inclusion of high-quality images, diplomatic and edited versions, searching, reusing, and accessibility. There are still further opportunities of using electronic publication for greater accessibility using EpiDoc's ability to display content in different ways, which haven't yet been realised, for example versions for the visually impaired. There is also potential for greater linking between inscriptions and other online resources like prosopographies (through SNAP:DRGN ${ }^{67}$ or the Lexicon of Greek Personal Names ${ }^{68}$ ) or gazetteers like Pleiades. ${ }^{69}$ This is already being experimented with (see Matthews \& Rahtz, 2013) and seems to be a logical next step as online infrastructure improves. There are some drawbacks for the researcher themselves, in that they cannot hope to continue updating projects indefinitely, but with stable and more affordable storage solutions there is the potential to return to the data, or for others to use it in the future.

\section{c. That digital methods are increasing the possible scope and content of research questions}

Ruhleder (1995) and others discuss the possibility that digital methods allow researchers to ask questions that would not have been feasible without electronic resources. Are these changes visible in EpiDoc projects? Certainly the ability for flexible and improved faceted searching of inscriptions is a welcome affordance of electronic publications, rather than relying on subjectively compiled indices in print editions. Projects like Papyri.info (and the recently established IDEs) which combine different corpora allow cross-searching. This could potentially allow researchers to ask more exhaustive questions of the historical record, and EpiDoc's wider adoption would improve interoperability between corpora, making these aggregating projects more feasible.

Whether this is already happening is hard to tell. There are no clear examples of research resulting from projects like InsAph which ask questions which would not be possible using traditional methods. Some of the inscriptions themselves have not been published before, but this in itself is an expansion of research along traditional lines (albeit with substantially more images and different

66 Perseids homepage http://sites.tufts.edu/perseids

67 Standards for Networking Ancient Prosopographies homepage http://snapdrgn.net

68 Lexicon of Greek Personal Names homepage http://www.lgpn.ox.ac.uk

69 Pleiades homepage http://pleiades.stoa.org 
versions of the output). The structured nature of EpiDoc inscriptions also allows for searching the inscriptions for things like abbreviations or deliberate erasures, in ways which a print version or a database simply transcribing Leiden as character strings do not. This could result in interesting potential philological or historical research. The reuniting of archaeological and epigraphic information, as Tupman (2010) argues, could also result in interesting studies of inscriptions by them in greater depth. Tupman's research into funerary monuments is a first example of this.

Bodard $(2008, \S 34)$ discusses the potential of EpiDoc to encourage reproducibility of results, something highly prized in the hard sciences. Because all of the content of InsAph is openly available, along with the tools to manipulate it, if a scholar produces research output by searching the corpus and drawing conclusions while making the process transparent, instead of just presenting the findings, further scholars would be able to reproduce these searches and confirm their results. "[The availability of source files] opens up the author of such a digital project to a new level of scrutiny, which may on the one hand cause some to feel nervous, but can only be good news for scholarship"(Bodard, 2008, §34).

These scholars could then improve or refine previous research to do their own research. This refers back to Ruhleder's claim that computing technology is equalizing scholarship in classics, something Bodard has also discussed $(2008, \S \S 14-16)$, both by reducing access costs to research, and by providing opportunities for students and early-career academics to participate in impactful scholarship and question existing points of view. Again, evidence of this practice actually occurring in classics is yet to be seen, but it would be an example of a change in research methods to favour reproducibility.

Other ways in which the EpiDoc corpora could be changing research is in facilitating new methods of interrogating the inscriptions. Text-mining can be carried out, allowing close examination of large numbers of inscriptions, for example as Marco Büchler has been doing with automatizing suggestions for missing or incomplete words (Büchler et al., 2012). It has also been harnessed to examine re-use and quotation of texts, which could show which texts were popular with later writers, and whether this varies by subject, location, or time period (Büchler et al., 2013). This kind of research could also be facilitated by projects like Perseids, which allows volunteers to annotate texts with the origins of quotations from other classical sources, and with infrastructure for canonical citation of sources, like the CITE architecture of the Homer Multitext project (Smith, 2010). Another project currently being undertaken with EpiDoc inscriptions is Sematia, ${ }^{70}$ which aims to provide a platform for doing morphological and syntactic annotations of inscriptions, using some of the same tools as Perseids.

\section{Conclusions}

This case study has endeavoured to assess the ways in which the digital projects using EpiDoc may be changing methods of research in classics. The hypotheses, drawn from relevant themes in the literature, focused on collaboration, electronic publishing, and the scope and content of research questions. There is evidence that EpiDoc's development and adoption has been highly collaborative, and its drive towards interoperability and open scholarship in epigraphy and papyrology is a positive move towards more collaborative work in those fields. There is also evidence of actual collaborative work using EpiDoc, in projects like Papyri.info, and hopefully more examples will emerge in the future.

EpiDoc-based projects such as Inscriptions of Aphrodisias are already taking advantage of many of the positive affordances of electronic publishing, with searchable corpora, different views of the same data, and hyperlinking. EpiDoc itself also has the advantage in epigraphy of truly capturing the structure of inscriptions marked-up with Leiden conventions, which other methods do not. Papyri. info allows volunteers to add data, and make public work which is in some way 'in progress', avoiding

70 Sematia homepage http://sematia.hum.helsinki.fi 
the problem of deciding when to finish working on a corpus, which may have to be financially and practically driven. Although not every project uses electronic publishing to its fullest extent, there is evidence that EpiDoc is improving access to, and quality of, epigraphic and papyrological corpora.

The final question, of whether EpiDoc is changing the scope or content of research questions, is the most uncertain. There is substantial scope for further research on this topic, both concerning EpiDoc and digital classics more broadly. At present there is not enough evidence to say positively that EpiDoc projects are changing the questions scholars are asking in epigraphy, but given the effect they are having on promoting collaboration and the electronic publishing of results, it is likely that this question will be easier to answer in the future.

EpiDoc was chosen as a representative case study for digital classics in general. What conclusions can be drawn for this wider community on the basis of the results? On collaboration, it seems that this is part of a larger movement in digital classics to involve people with different expertise on digital projects. Most of the articles published in Dunn and Mahony (2013) and Crane and Terras (2009) were co-authored, and even those with single authors there and in Bodard and Mahony (2008) and Bodard and Mahony (2010) generally describe projects with several collaborators. Digital classicists frequently share ideas and work with digital humanities scholars and developers more generally (for example, many of the speakers in the Institute for Classical Studies' (ICS) Digital Classicist seminar series have been from the digital humanities community). ${ }^{71}$ It has, by contrast, been the collaboration between digital and traditional classicists which has been harder to establish, but this seems to be improving, as evidenced by the Dunn and Mahony (2013) volume being published by the Institute of Classical Studies, who have also been integral to the organisation of the annual ICS Digital Classicist seminar series for the past ten years. Further, we have recently seen the ICS appoint a Reader in Digital Classics. Hopefully, this trend will continue, and collaboration on digital projects will continue to proliferate throughout the community, just as word processing has become ubiquitous since Brunner's time.

On electronic publishing, EpiDoc has been developed to meet epigraphers' (and now papyrologists') particular needs, which are different from publishing in other areas of classics. There has always been a tradition of publishing large corpora of inscriptions, with transcriptions and commentary, and EpiDoc has been important in bringing this publishing tradition online and extending the possibilities. In addition, the EpiDoc community promote its use with a series of workshops and Summer Schools to disseminate skills, promote discussion and widen participation within the community itself. ${ }^{72}$ As the case study analysis showed, it has been relatively successful, but there is room for more experimentation and improvement, and the further adoption of EpiDoc would be beneficial for promoting interoperability in epigraphy. In the rest of classics, there are similar movements towards electronic publishing, particularly in the case of digital critical editions, and much work is being done to build infrastructure there (see Franzini et al 2016). This would be an ideal area for a case study similar to this one, assessing how these digital critical editions work and their impact on scholars studying the texts.

Are digital projects changing the questions researchers are asking? This was a hypothesis in the case study, and which has not been satisfactorily answered. There was insufficient evidence to comment at this stage, but hopefully in the future more will emerge from the many EpiDoc projects which are still being developed (Inscriptions of Roman Tripolitania, Integrating Digital Epigraphies, the U.S. Epigraphy Project). This is also a fascinating question for digital classics more widely, and future research could focus on entirely different kinds of digital projects, for example digital critical editions, computer modelling, or textual analysis.

Computers have long been a part of classical research. Their uses have changed over time,

71 Digital Classicist Summer 2015 programme http://www.digitalclassicist.org/wip/wip2015.html 72 See for example the EpiDoc Workshop and Summer School announcements: https://wiki.digitalclassicist. org/EpiDoc_Summer_School 
and their potential remains huge. This study has, by examining the variety of digital projects pervading classics at the present moment, and focusing on one representative slice of them, EpiDoc, considered the crucial question of how computing technologies are changing research. The evidence in favour of collaboration and electronic publishing has already been discussed, but there is still great potential for further investigation. Equally, there were other potential hypotheses suggested by the literature which could not be dealt with here: a growing focus on electronic infrastructure, for example. And given the number of burgeoning projects in almost every area of classics at the present time, in another five years, these questions may have different or more definite answers. For now, EpiDoc gives us reasons to be optimistic about the possibilities of digital projects in epigraphy, papyrology, and classics more widely, promoting collaboration, open scholarship, and interoperability, which are all crucial to enable the best possible scholarship in classics in the future.

\section{References}

Almas, B. \& Beaulieu, M.-C. (2016). The Perseids Platform: Scholarship for all! In Bodard, G. \& Romanello, M. (Eds.), Digital Classics Outside the Echo-Chamber: Teaching, Knowledge Exchange \& Public Engagement (pp. 171-186). London: Ubiquity Press.

Babeu, A. (2011). 'Rome Wasn't Digitized in a Day': Building a Cyberinfrastructure for Digital Classicists. Washington, DC: Council on Library and Information Resources. Retrieved from http://www.clir.org/pubs/reports/reports/pub150/pub150.pdf

Barker, E. (2015, February 2). Mapping Herodotus: Countercartography, Networks and Bottomless Maps. Presented at the Digital Classics, Ancient History Seminar, Spring Term 2015, Oxford. Retrieved from http://www.podcasts.ox.ac.uk/digital-classics-mapping-ancient-worldcountercartography-networks-and-bottomless-maps

Baumann, R. (2013). The Son of Suda On-Line. In Dunn, S. \& Mahony, S. (Eds.), The Digital Classicist 2013 (pp. 91-106). London: Institute of Classical Studies, School of Advanced Study, University of London.

Bevan, A. (2013). Travel and Interaction in the Greek and Roman World: A Review of Some Computational Modelling Approaches. In Dunn, S. \& Mahony, S. (Eds.), The Digital Classicist 2013 (pp. 3-24). London: Institute of Classical Studies, School of Advanced Study, University of London.

Blackwell, C. \& Crane, G. (2009). Conclusion: Cyberinfrastructure, the Scaife Digital Library and Classics in a Digital Age. Digital Humanities Quarterly, 3, no. 1. Retrieved from http://www. digitalhumanities.org/dhq/vol/3/1/000035/000035.html

Blanke, T., Hedges, M. \& Rajbhandari, S. (2013). Towards a Virtual Data Centre for Classics. In Dunn, S. \& Mahony, S. (Eds.), The Digital Classicist 2013 (pp. 81-90). London: Institute of Classical Studies, School of Advanced Study, University of London.

Bodard, G. (2010). EpiDoc: Epigraphic Documents in XML for Publication and Interchange. In Feraudi-Gruénais, F. (Ed.), Latin on Stone: Epigraphic Research and Electronic Archives (pp.101-18). Lanham: Lexington Books.

Bodard, G. (2008). The Inscriptions of Aphrodisias as Electronic Publication: A User's Perspective and a Proposed Paradigm. Digital Medievalist, 4, 37 paragraphs. Retrieved from http://www. digitalmedievalist.org/journal/4/bodard/

Bodard, G. \& Garcés, J. (2009). Open Source Critical Editions: A Rationale. In Deegan, M. \& Sutherland, K. (Eds.), Text Editing, Print and the Digital World (pp. 84-98). Farnham: Ashgate.

Bodard, G. \& Mahony, S. (Eds.). (2010). Digital Research in the Study of Classical Antiquity. Farnham: Ashgate.

Bodard, G. \& Mahony, S. (Eds.). (2008). 'Though Much Is Taken, Much Abides': Recovering antiquity through innovative digital methodologies (Digital Classicist/Digital Medievalist Special Issue). Digital Medievalist, 4, 194 paragraphs. Retrieved from http://www.digitalmedievalist.org/ journal/4/ 
Bodard, G. \& Romanello, M. (Eds.) (2016), Digital Classics Outside the Echo-Chamber: Teaching, Knowledge Exchange \& Public Engagement. London: Ubiquity Press. DOI: http://dx.doi. org/10.5334/bat.j. License: CC-BY 4.0. Retrieved from http://www.ubiquitypress.com/site/ books/detail/21/digital-classics-outside-the-echo-chamber.

Bodard, G. \& Stoyanova, S. (2016). Epigraphers and Encoders: Strategies for Teaching and Learning Digital Epigraphy. In Bodard, G. \& Romanello, M. (Eds.), Digital Classics Outside the Echo-Chamber: Teaching, Knowledge Exchange \& Public Engagement (pp. 51-68). London: Ubiquity Press.

Brunner, T. F. (1993). Classics and the Computer: The History of a Relationship. In Solomon, J. (Ed.), Accessing Antiquity: The Computerization of Classical Studies (pp. 10-33). Tucson: University of Arizona Press.

Büchler, M., Geßner, A., Berti, M. \& Eckart, T. (2013) Measuring the Influence of a Work by Text Re-Use. In Dunn, S. \& Mahony, S. (Eds.), The Digital Classicist 2013 (pp. 63-79). London: Institute of Classical Studies, School of Advanced Study, University of London.

Büchler, M., Kruse, S. \& Eckart, T. (2012). Bringing Modern Spell Checking Approaches to Ancient Texts - Automated Suggestions for Incomplete Words. In Proceedings of Digital Humanities 2012. Hamburg.

Cayless, H. (2003). Developing a Toolkit for Digital Epigraphy. In Rochester, E. \& Kretzschmar, Jr., W. A. (Eds.), ALLC/ACH 2003 Conference Abstracts (pp. 155-6). Athens, GA.: The University of Georgia. Retrieved from http://citeseerx.ist.psu.edu/viewdoc/download?doi=10.1.1.91.5363 \&rep=rep1\&type=pdf

Cayless, H. (2015, July 17). Integrating Digital Epigraphies (IDEs). Presented at the Digital Classicist London \& Institute of Classical Studies seminar 2015. Retrieved from http://www. digitalclassicist.org/wip/wip2015-07hc.html

Cayless, H., Roueché, C., Elliott, T. \& Bodard, G. (2009). Epigraphy in 2017. Digital Humanities Quarterly, 3, no. 1. Retrieved from http://www.digitalhumanities.org/dhq/vol/3/1/000030/000030. $\underline{\mathrm{html}}$

Clarke, A., Fulford, M., Rains, M. \& Shaffrey, R. (2001). The Victorian Excavations of 1893. Silchester Roman Town - The Insula IX Town Life Project. Retrieved from https://www.reading.ac.uk/ silchester/i3/victorians/vic home.php

Crane, G. (2004). Classics and the Computer: An End of the History. In Schreibman, S., Siemens, R. \& Unsworth, J. (Eds.), A Companion to Digital Humanities. Malden, MA.: Blackwell Publishing. Retrieved from http://www. digitalhumanities.org/companion

Crane, G. \& Terras, M. (Eds.). (2009). Changing the Center of Gravity: Transforming Classical Studies Through Cyberinfrastructure. Digital Humanities Quarterly, 3, no. 1. Retrieved from http://www.digitalhumanities.org/dhq/vol/3/1/index.html

Crane, G., Seales, B \& Terras, M. (2009). Cyberinfrastructure for Classical Philology. Digital Humanities Quarterly, 3, no. 1. Retrieved from http://www.digitalhumanities.org/dhq/ $\mathrm{vol} / 3 / 1 / 000023 / 000023 . \mathrm{html}$

Creative Commons - Attribution 3.0 Unported - CC BY 3.0. (n.d.). Retrieved from https:// creativecommons.org/licenses/by/3.0

Dee, S., Foradi, M. \& Šarić, F. (2016). Learning By Doing: Learning to Implement the TEI Guidelines Through Digital Classics Publication. In Bodard, G. \& Romanello, M. (Eds.), Digital Classics Outside the Echo-Chamber. Teaching, Knowledge Exchange \& Public Engagement (pp. 1532). London: Ubiquity Press.

Dunn, S. \& Mahony, S. (Eds.). (2013). The Digital Classicist 2013. London: Institute of Classical Studies, School of Advanced Study, University of London.

Edmunds, L. (Fall, 1995-Winter, 1996). Computers and the Classics: The Third Phase. Arion: A Journal of Humanities and the Classics, 3, no. 2/3, 317-50. Retrieved from http://www.jstor. org/stable/20163591

Elliott, T. (2012). Aphrodeisias: a Pleiades Name resource. Retrieved from http://pleiades.stoa.org/ 
places/638753/aphrodeisias

Elliott, T., Bodard, G., Mylonas, E., Stoyonava, S., Tupman, C., Vanderbilt, S., et al. (2007-2016). EpiDoc Guidelines: Ancient Documents in TEI XML; Appendix: Glossary (Version 8). Retrieved from http://www.stoa.org/epidoc/gl/latest/app-glossary.html

Felle, A. E. \& Rocco, A. (Eds.). (2016). Off the Beaten Track: Epigraphy at the Borders: Proceedings of the VI EAGLE International Event. Oxford: Archaeopress Publishing Ltd. Retrieved from www.archaeopress.com/ArchaeopressShop/Public/download.asp?id $=\{$ E7B2AAC6-99864C41-9842-6AA93BE7ACD9\}

Feraudi-Gruénais, F. (Ed.). (2010). Latin on Stone: Epigraphic Research and Electronic Archives. Lanham: Lexington Books.

Foka, A. (2014). Reflecting on Our (first Ever) Digital Classicist Wiki Sprint. The Stoa Consortium, July 16, 2014. Retrieved from http://www.stoa.org/archives/1977

Franzini, G., Terras, M. \& Mahony, S. (2016). A Catalogue of Digital Editions. In Pierazzo, E. \& Driscoll, M. J. (Eds.), Digital Scholarly Editing: Theories and Practices (pp. 161-182). Cambridge: Open Book Publishers. Retrieved from http://www.openbookpublishers.com/product/483/digitalscholarly-editing--theories-and-practices

Fulford, M. G., O'Riordan, E. J., Clarke, A. \& Rains, M. (2010). Silchester Roman Town: Developing Virtual Research Practice 1997-2008. In Bodard, G. \& Mahony, S. (Eds.), Digital Research in the Study of Classical Antiquity (pp. 15-34). Farnham: Ashgate.

Gaffney, V., Murgatroyd, P., Craenen, B. \& Theodoropoulos, G. (2013). 'Only Individuals': Moving the Byzantine Army to Manzikert. In Dunn, S. \& Mahony, S. (Eds.), The Digital Classicist 2013 (pp. 25-44). London: Institute of Classical Studies, School of Advanced Study, University of London.

Gruber, E., Bransbourg, G., Heath, S. \& Meadows, A. (2013). Linking Roman coins: Current work at the American Numismatic Society. In Earl, G., Sly, T., Chrysanthi, A., Murrieta-Flores, P., Papadopouos, C., Romanowska, I. \& Wheatley, D. (Eds.), Archaeology in the Digital Era: Papers from the 40th Annual Conference of Computer Applications and Quantitative Methods in Archaeology (CAA), Southampton, 26-29 March 2012 (pp. 249-58). Amsterdam: Amsterdam University Press.

Hardwick, L. (2000). Electrifying the Canon: The Impact of Computing on Classical Studies. Computers and the Humanities, 34, 279-95. Retrieved from http://www.jstor.org/stable/30204820

Heath, S. (2010). Diversity and Reuse of Digital Resources for Ancient Mediterranean Material Culture. In Bodard, G. \& Mahony, S. (Eds.), Digital Research in the Study of Classical Antiquity (pp. 35-52). Farnham: Ashgate.

Isaksen, L., Simon, R., Barker, E. \& de Soto Cañamares, P. (2014). Pelagios and the emerging graph of ancient world data. In WebSci '14: Proceedings of the 2014 ACM conference on Web science, (pp. 197-201). New York: ACM. Retrieved from http://oro.open.ac.uk/43658

Löser, L. (2014). The March of IDEs - How Integrating Digital Epigraphies Could Facilitate Scholarly Use of Epigraphic Material. Dissertation in Ancient History, University of St Andrews. Retrieved from http://www.academia.edu/10674038/The March of IDEs - How Integrating Digital Epigraphies could facilitate scholarly use of epigraphic material

Matthews, E. \& Rahtz, S. (2013). The Lexicon of Greek Personal Names and Classical Web Services. In Dunn, S. \& Mahony, S. (Eds.), The Digital Classicist 2013 (pp. 107-24). London: Institute of Classical Studies, School of Advanced Study, University of London.

Monella, P. (2008). Towards a Digital Model to Edit the Different Paratextuality Levels within a Textual Tradition. Digital Medievalist, 4, 58 paragraphs. Retrieved from http://www.digitalmedievalist. org/journal/4/monella

Murgatroyd, P., Craenen, B., Theodoropoulos, G., Gaffney, V. \& Haldon, J. (2011). Modelling Medieval Military Logistics: An Agent-Based Simulation of a Byzantine Army on the March. Computational and Mathematical Organization Theory, 18, no. 4, pp. 488-506.

Perseus Collections/Texts. (n.d.). Retrieved from http://www.perseus.tufts.edu/hopper/collections 
Orlandi, S., Santucci, R., Casarosa, V. \& Liuzzo, P. M. (Eds.). (2014). Information Technologies for Epigraphy and Cultural Heritage: Proceedings of the First EAGLE International Conference. Rome: Sapienza Università Editrice. Retrieved from http://www.eagle-network.eu/wp-content/ uploads/2015/01/Paris-Conference-Proceedings.pdf

Pierazzo, E. \& Driscoll, M. J. (Eds.) (2016) Scholarly digital editions: Theory, practice and future perspectives. Cambridge: Open Book Publishers.

Reynolds, J., Roueché, C. \& Bodard, G. Inscriptions of Aphrodisias (2007). Retrieved from http:// insaph.kcl.ac.uk/iaph2007

Roueché, C. (2004). Aphrodisias in Late Antiquity: The Late Roman and Byzantine Inscriptions (revised second edition). Retrieved from http://insaph.kcl.ac.uk/ala2004

Roueché, C. (1989). Aphrodisias in Late Antiquity: The Late Roman and Byzantine Inscriptions Including Texts from the Excavations at Aphrodisias Conducted by Kenan T. Erim. London: Society for the Promotion of Roman Studies.

Ruhleder, K. (1995). Reconstructing Artifacts, Reconstructing Work: From Textual Edition to On-Line Databank. Science, Technology, \& Human Values, 20, 39-64. Retrieved from http://www.jstor. org/stable/689880

Smith, N. (2010). Digital Infrastructure and the Homer Multitext Project. In Bodard, G. \& Mahony, S. (Eds.), Digital Research in the Study of Classical Antiquity (pp. 121-38). Farnham: Ashgate.

Talbert, R. J. A. (2000). Barrington Atlas of the Greek and Roman World. Princeton, N.J.: Princeton University Press.

Terras, M. (2010). The Digital Classicist: Disciplinary Focus and Interdisciplinary Vision. In Bodard, G. \& Mahony, S. (Eds.), Digital Research in the Study of Classical Antiquity (pp. 171-89). Farnham: Ashgate.

TLG - About. (n.d.). Retrieved from http://stephanus.tlg.uci.edu/tlg.php

Toufexis, N. (2010). One Era's Nonsense, Another's Norm: Diachronic Study of Greek and the Computer. In Bodard, G. \& Mahony, S. (Eds.), Digital Research in the Study of Classical Antiquity (pp. 105-20). Farnham: Ashgate.

Tupman, C. (2010). Contextual Epigraphy and XML: Inscribed Funerary Monuments. In Bodard, G. \& Mahony, S. (Eds.), Digital Research in the Study of Classical Antiquity (pp. 73-86). Farnham: Ashgate.

Unsworth, J. (2000). Scholarly Primitives: What Methods Do Humanities Researchers Have in Common, and How Might Our Tools Reflect This? Retrieved from http://people.brandeis. edu/ unsworth/Kings.5-00/primitives. html 


\section{Panta Rei}

PANTA REI es una revista digital de investigación orientada a la Historia y otras ciencias afines. Su principal objetivo es la transmisión del conocimiento científico, dando una oportunidad también a los jóvenes investigadores que quieren abrirse camino en el estudio de las ciencias humanas y sociales. Se compone de estudios originales relacionados con la disciplina histórica así como su didáctica y difusión. Las diferentes secciones que componen la revista son: artículos de investigación, entrevistas a profesionales, recensiones de monografías de actualidad y crónicas de congresos o eventos científicos relevantes.

Todos los artículos publicados son objeto de un proceso de revisión a cargo de un mínimo de dos evaluadores, que se consideran expertos en el ámbito temático del artículo propuesto. Nuestro deseo es poder ofrecer unos contenidos rigurosos, de calidad y de interés.

EI CEPOAT (Centro de Estudios del Próximo Oriente y la Antigüedad Tardía de la Universidad de Murcia) es la institución encargada de la coordinación y gestión de la revista, desde donde anualmente se lanzará la convocatoria para aquellos que estén interesados en publicar sus trabajos, siempre relacionados con la Historia, Arqueología, Historia del Arte, Didáctica de las Ciencias Sociales, etc.

PANTA REI is a digital journal focused on History and other sciences related to it. Its main objective is the transmission of scientific knowledge by giving also an opportunity to young researchers who want to make their way in the study of human and social sciences. It is composed by original studies related to History, as well as its didactics and promotion. The different sections of this journal are: research articles, interviews to professionals, recensions on monographs about current issues and reports about congresses or relevant scientific events.

All the articles published are subject to a revision process carried out by a minimum of two reviewers who are considered to be experts in the field of the article proposed. Our wish is to offer rigorous contents with quality and being of interest to the reader.

CEPOAT (Centre of Studies of the Middle East and Late Antiquity of the University of Murcia) is the institution in charge of the coordination and management of this journal. This is the centre from where the call for papers will be launched for all the people interested in publishing their papers, always related to History, Archeology, Art History, Didactics of the Social Sciences, etc. 


\section{Normas de Publicación}

El autor se compromete a enviar trabajos originales, que no se encuentren publicados en otras revistas ni en otros idiomas. Así mismo, el mismo artículo no podrá ser presentado en otras revistas mientras dure el proceso de evaluación.

\section{Envío y presentación de originales}

Los artículos se enviarán exclusivamente a través del correo electrónico a la dirección pantarei@um.es. Los textos serán enviados en formato DOC y las imágenes en formato JPEG o TIFF, y con un tamaño mínimo de 2000 px. Éstas no aparecerán incorporadas en el texto, sino enviadas en archivo aparte y correctamente numeradas según su posición en el texto. Junto al trabajo, se rellenará y enviará un documento aparte en el que se especifiquen los datos del autor siguiendo el modelo disponible en la página Web de la revista.

Para la redacción de los trabajos se tendrá en cuenta el Manual de la American Psychological Association, en su sexta edición. La extensión máxima de los trabajos será de 30 páginas. La tipografía será Arial 11, con interlineado sencillo y sin espacio alguno entre párrafos. El texto deberá ir justificado a ambos márgenes y sin sangría en los primeros párrafos. Los márgenes serán de $2,50 \mathrm{~cm}$. En los casos en los que fuera necesario incorporar notas, éstas irán a pie de página, enumeradas consecutivamente, con tipografía Arial 10, interlineado sencillo y justificadas a ambos márgenes.

Una información más detallada se encuentra disponible en la página http://www.um.es/cepoat/ pantarei.

\section{Proceso de valoración y evaluación}

Una vez recibidos los trabajos, la Revista realizará una primera valoración. Si el trabajo enviado se ajusta a las normas de presentación propuestas, la temática es coincidente con la línea editorial de la revista y posee la calidad científica necesaria, será remitido al consejo asesor para una primera evaluación. Si no es así en este primer paso se puede rechazar directamente los documentos que incumplan claramente la línea editorial.

Será el Consejo Asesor quien indique a la revista la originalidad, relevancia, estructura, redacción, aparato bibliográfico, etc. del trabajo enviado y, para ello, se designará a dos revisores expertos externos que evaluarán cada uno de los trabajos, que pueden formar parte (o no) de este Consejo Asesor. La selección de los revisores se ajustará a la temática y características metodológicas del trabajo. El nombre y filiación de los autores serán eliminados del trabajo para su revisión, así como los revisores actuarán de manera anónima y confidencial.

Los revisores deberán rellenar un informe de evaluación que centrará su atención en aspectos tales como características formales, originalidad y novedad de los trabajos, relevancia de las propuestas y los resultados, calidad metodológica y validez científica.

Una vez terminado el proceso se decidirá la aceptación o no de los mismos y su publicación en el número que sea pertinente, así como las modificaciones susceptibles de ser realizadas para su final publicación. Dicha notificación se enviará únicamente por correo electrónico, en un plazo máximo de seis meses. 


\section{Publishing rules}

The author is committed to submit original papers not having been published in other reviews or in other languages. In this way, it is not allowed for the same paper to be presented in other reviews during the evaluation process.

\section{Submission and presentation of originals}

The articles will be exclusively submitted by email to pantarei@um.es. The texts will be submitted in DOC format and the images in JPEG or TIFF format, and with a minimum size of 2000 px. Images will not be integrated in the text but sent in another file and properly numbered according to their position in the text. Attached to the paper, a document will be filled out and sent where the author's data will be specified following the model available on the website.

The sixth edition of the Manual of the American Psychological Association will be taken into account for the writing of the papers. The length of the papers must not exceed 30 pages. Typography will be Arial 11 , with simple line spacing and no space between paragraphs. The text must be justified on both margins without indentation in the first paragraphs. Margins size will be $2.50 \mathrm{~cm}$. Where it could be necessary the incorporation of notes, they will be at the bottom of the page, consecutively numbered with typography Arial 10, simple line spacing and justified on both margins.

More detailed information is available on the website: http://www.um.es/cepoat/pantarei.

\section{Examination and assessment process}

The Journal will submit the papers to a first examination once received. If the paper follows the presentation guidelines, the subject agrees with the editorial line of this journal, and possess the scientific quality required, it will be sent to the advisory council for a first assessment. If not, the documents which clearly fail to complete the editorial line may be rejected straightaway in this first step.

The Advisory Council will indicate the originality, relevance, structure, writing, bibliography, etc. of the text to the journal; for this purpose, two outside experts will be designated to review the papers; these experts can be (or not) part of this Advisory Council. The selection of the experts will adjust to the subject and methodological characteristics of the paper. Name and affiliation of the author will be eliminated from the text for its review, in this way experts will act anonymously and confidentially.

The experts will fill out an assessment report which will focus on aspects such as formal characteristics, originality and novelty of the papers, relevance and results of the proposal, methodological quality and scientific validity.

Once the process is finished, the acceptance or not of the papers and its publication in the corresponding edition will be decided, as well as the modifications that may be done for its final publication. This notification will be sent by email within 6 months maximum. 


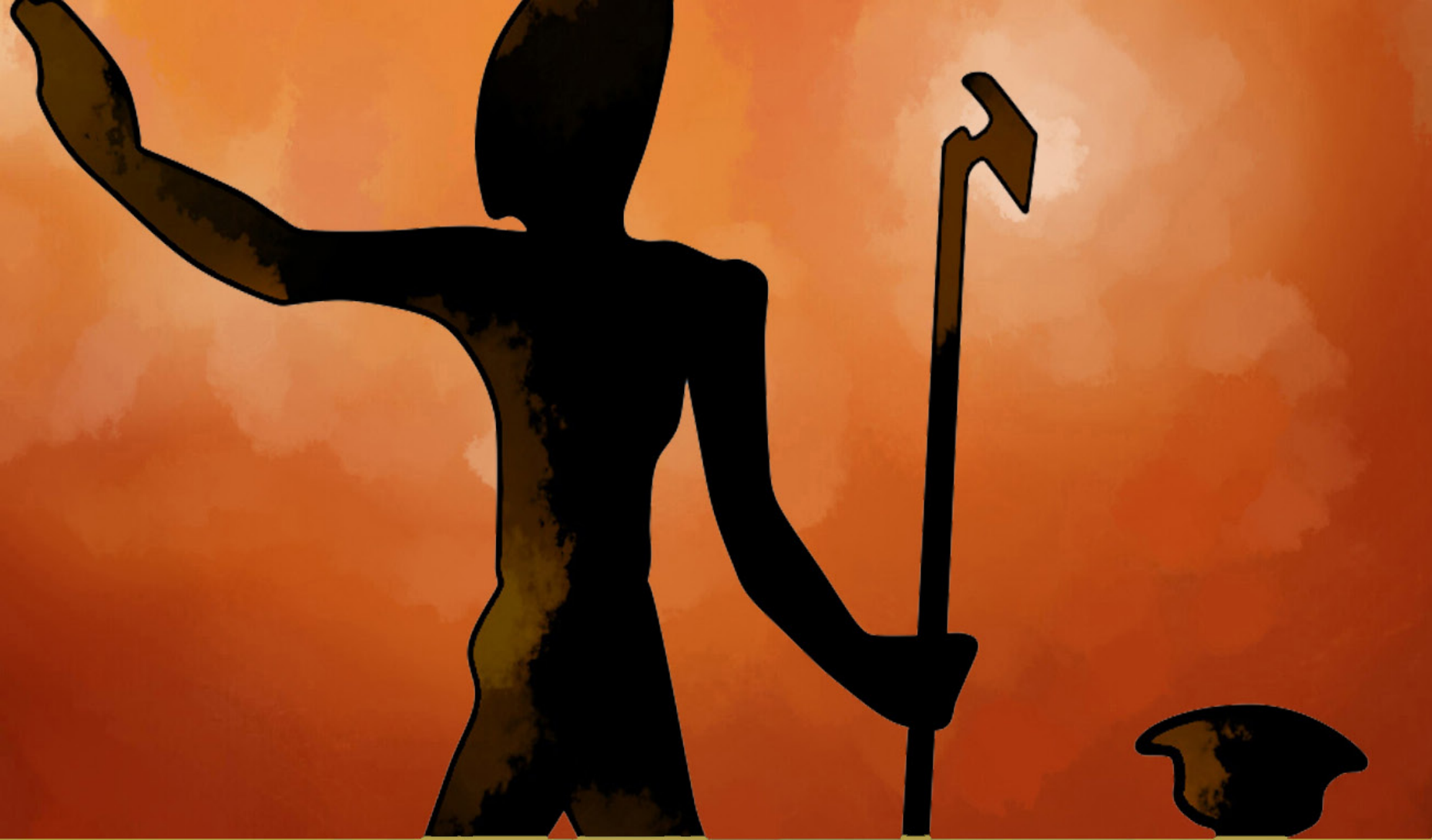

cepo t

UNIVERSIDAD DE MURCIA

centro de estudios del

próximo oriente y la

antigüedad tardía 